811.163.41"17/18"

811.163.41'373.611

821.163.41.08-2 Вујић Ј.

https://doi.org/10.18485/sj.2017.22.1.25

ТОМИСЛАВ М. МАТИЋ

Универзитет у Београду

Филолошки факултет
Оригинални научни рад

Примљен: 21. 07. 2016.

Прухваћен: 15. 12. 2016.

\title{
СЛОЖЕНЕ ТВОРЕНИЦЕ У КРЕШТАЛИЦИ \\ ЈОАКИМА ВУЈИЋА И ЊИХОВИ АНАЛОГОНИ \\ У САВРЕМЕНОМ СРПСКОМ ЈЕЗИКУ
}

\begin{abstract}
У раду ће бити анализиране сложене творенице ексцерпиране из драме Крешталица Јоакима Вујића. Опширном и свеобухватном формално-морфолошком анализом сложених конструкција са форманотом благо- ће се, уз цитирање адекватног контекста, покушати утврдити њихови аналогони у савременом језику и објаснити степен и модел адаптације (трансфера) забележених сложеница у данашњи језички израз.
\end{abstract}

Кључне речи: Јоаким Вујић, Крешталица, сложене творенице, сложенице, аналогон, славеносрпски језик, савремени српски језик.

\section{1. ИСТОРИЈАТ ПИТАњА}

\section{1 О књижевном делу и језику драма Јоакима Вујића}

Јоаким Вујић, означен и упамћен као оснивач српског театра, обележио је својим радом и делима један веома интересантан и турбулентан културноисторијски период у расту и развоју српског друштва и државе. Класицизам и просветитељство, повоји романтизма и дефинисања нација у Европи, период тројезичја у Срба као прилично пластичан показатељ труда једног народа да

"t.matic@yahoo.com 
се изрази, да дефинише свој језички и културни израз, дефинишући тако и обрисе свога идентитета за који се одлучио борити. Управо у таквом вртлогу утицаја и узуса живи и ствара, пише драме, аутобиографију и поуке, путописе, граматичке приручнике и језичке огледе, преводи, Јоаким Вујић; и све то се и те како огледа у његовом језичком изразу.

О животу и књижевном делу Јоакима Вујића писано је у мери мањој него што то оснивач српскога театра заслужује. Радова је било, почев од радова Из живота Јоакима Вујића Павла Поповића и Ћирилица и аустријске власти Димитрија Руварца с почетка XX века (1907. и 1909), преко радова из тридесетих година истог века (П. Поповић, Д. Руварац, Б. Стојковић, Св. Матић и др.) па до зборника приређених у његову част, О театарском делу Јоаким Вујића из 1988. и Зборника МС за сиенске уметности и музику 6/7 из 1990. године и појединачних радова у XXI веку. Заједничко за готово све радове на које смо наилазили испитујући грађу јесте да се они углавном односе на литерарни опус Вујићев или детаље из његова живота који би тај опус учинили разумљивијим.

О језику његових дела, с друге стране, било је јако мало радова. Као редак детаљан изучавалац самог језика Вујићевих дела, понајвише драма, издваја се Александар Албијанић (Албин), лингвиста из Новог Сада, односно Лос Анђелеса, са серијом радова о фонетским, морфолошким, синтаксичким и лексичким особинама језика Јоакима Вујића. Радови су објављивани у двама нашим језичким зборницима, Зборнику МС за филологију и лингвистику и Научном састанку слависта у Вукове дане у периоду од 1976. до 1986. године.

У првом раду из 1976. године Албијанић заправо само разматра језик писаца из Војводине предвуковског периода, ослањајући се на језик превода Јована Рајића из 1793. Собраније разних недјелних и праздничних нравоучителних поученији. Иако се у том раду не анализира језик Јоакима Вујића, значајан је јер се њиме аутор представио као будући изучавалац језика писаца из доба тројезичја, у нашем случају конкретно језика Јоакима Вујића као једног од књижевних протагониста тога времена. Већ у следећем раду уводи два нова писца, Павла Соларића и Јоакима Вујића, и анализира деклинацију позајмљеница у седам њихових дела, шест дела Јоакима Вујића и једном делу Павла Соларића (Албијанић 1981). Ово је веома јасан индикатор да ће се у наредним његовим радовима сва пажња усмерити на језичке карактеристике само Вујићева дела.

У раду из 1982. године Албијанић на самом почетку истиче да је Јоаким Вујић, с мало изузетака, занемарен и лоше схваћен са литерарне и нарочито са филолошке стране (Албијанић 1982: 44). У овом раду аутор, ослањајући се на претходне радове Александра Младеновића, анализира фонетске и морфолошке црте у три Вујићеве драме: Фернандо и Јарика, Љубовнаја завист чрез 
једне ичиеле и Слепи миш, раздвајајући их на народне и рускословенске. У следећем раду аутор уводи и анализу синтаксичких специфичности Вујићева језика, истовремено проширујући корпус у односу на претходни рад са још две драме: Награжденије и наказаније и Крешталииа. У закључку наглашава да без устручавања можемо рећи да се Јоаким Вујић користио углавном чистим народним, а не рускословенским језиком у својим представама, те да би било интересантно упоредити позоришни с његовим прозним језиком да бисмо имали јаснију слику о литерарном језику којим се служио отаи српског позоришта (Албијанић 1983: 78). У раду из 1985. године Албијанић заиста своју анализу помера са језика драмских текстова и проширује је на Језик белетристике Јоакима Вујића, анализирајући шест прозних дела ${ }^{1}$, задржавајући исти образац у испитивању специфичних фонетских, морфолошких и синтаксичких језичких црта.

\section{2 О сложеницама у делима српских писаца XVIII и XIX века}

За прасловенски језик није била карактеристична употреба сложених твореница. Међутим, већ у самом настанку словенског књижевног језика, у преводима с грчког у ћирилометодијевско доба, потребе превођења наметнуле су стварање великог броја сложеница, ... , нарочито за потребе вишег, свечаног стила (Стијовић 1992: 101-102). Може се рећи да је експанзија овог творбеног модела постала једна од препознатљивијих одлика српског књижевног језика почев од српске редакције старословенског - српскословенског ${ }^{2}$. Славеносрпски језик се својим дистанцирањем од народног језичког израза сврстава у одређени тип вишег регистра, стила, за који важе сличне иманентне карактеристике као и на почецима стварања српског књижевног језика. Једна од њих свакако јесте и наглашена употреба сложених твореница.

Један од начина да се утврди број и тип радова о сложеним твореницама у периоду српског тројезичја, односно у периоду славеносрпског језика, јесте осврт на монографије о језику истакнутих представника књижевности и културе тога времена. Таквих је радова у нашој лингвистичкој литератури било прилично доста, и то из пера истакнутих наших лингвиста, од Јована Кашића, с краја шездесетих XX века, па до Александра Милановића, из 2014. године. Треба нагласити да се, ако говоримо о (условним) представницима

\footnotetext{
${ }^{1}$ Радостне и увеселителне лакрдије Бертолдина; Увеселителне басне Какасене; Алексис и Надина; Млади Робинсон; Благородна и великодушна жена Лунара; Излишнаја љубов Ирине и Филандра.

${ }^{2}$ Овде ваља истаћи монографију Сложенице у оригиналним српскословенским дјелима сакралног карактера Зорице Никитовић у којој се детаљно и са више аспеката приступа анализи сложеница у српскословенском језику.
} 
славеносрпског језика и периода, подразумева да најчешће говоримо о писцима с подручја данашње Војводине.

У студији Језик Милована Видаковића Јован Кашић детаљно осветљава пишчев језик од Графије и правописа до Лексике и фразеологије. У овом потоњем Кашић се само унеколико дотиче и сложених твореница у Видаковићевом језику, и то у одељку Речи страног порекла. Занимљиво је да у одељку Творба речи нема говора о евентуалним речима насталим слагањем (Кашић 1968: 138-142).

У одељку Лексика у студији Језичке карактеристике књижевних дјела Доситеја Обрадовића (Куна 1970: 215-262) Херта Куна на почетку детаљно приступа сложеницама, посматрајући их кроз три засебне категорије: Сложени придјеви, сложене именице и сложени глаголи. У првим двема категоријама акценат је на слагању као творбеном процесу, док се код глагола у први план истиче специфична префиксација. Говорећи о сложеним именицама аутор истиче да највећи број сопствених Доситејевих сложених имена одговара већ постојећим калупима у том смислу што се у првом дијелу код сложених именица појављује лексема која се ријеђе или чешће јавља код сложених имена и у традиционалном лексичком фонду, било код Поликарпова или код Срезњевског, докје у другом дијелу сложенище Доситејев избор био слободан, тј. служио је за давање новог значења (Куна 1970: 220). Затим се наводи тридесетак најфреквентнијих форманата које је Доситеј користио, а за нас је интереснатно да је први међу њима формант благо-.

Јован Јерковић у књизи Језик Богобоја Атанацковића сложенице анализира индиректно и спорадично, у делу Лексика и фразеологија, и то приликом навођења конкретних примера позајмљеница (Јерковић1976: 133-137). У студијама Кюижевни језик Имануила Јанковића Питера Херитија и Језик Јована Хацића Љиљане Суботић не даје се посебан осврт на творбене језичке карактеристике.

Књига Александра Милановића Језик Јована Суботића својим обимом и разноврсношћу обухваћеног свакако представља најисцрпнију студију о језику неког од писаца овог периода. Уз очекиване и у свим претходним студијама обрађиване теме из графије, ортографије, вокалског система и морфологије даје се опширан приказ творбе речи, лексике и синтаксе Суботићева језика. У одељку о творби речи (Милановић 2014: 273-321) јасно су омеђена три дела која се баве сложеним твореницама: композиција именица, композиција придева и композиција глагола. У одељку Композиција именица аутор приказује доминантне типове сложеница из два угла: првог форманта сложенице и суфикса карактеристичног за други део сложенице. Када је у питању позиција првог творбеног форманта, најфреквентнији су благо- и велико-, док као најтипичније суфиксе другог форманта аутор издваја -ије, -осm, -ство и -ац. На 
крају овог одељка аутор даје осврт на конкуренцију у именичким сложеницама где осветљава примере кад други део именичких сложеница са апстрактним значењем долази у конкурентски однос захваљујући појави исте основе и различитих синонимних суфикса (Милановић 2014: 310$)^{3}$. У одељку о композицији придева аутор преко шест најтипичнијих првих форманата наводи групе примера традиционалних славенизама, док у одељку о композицији глагола истиче, цитирајући пређашња истраживања, да сложених глагола има јако мало у српском језику, те да их је мало било и у језику Суботићева времена.

\section{2. СЛОЖЕНЕ ТВОРЕНИЦЕ У КРЕШТАЛИЦИ ЈОАКИМА ВУЈИЋА}

Грађа за рад ексцерпирана је из Нолитовог издања Изабраних драма Јоакима Вујића из 1987. године. У обзир за разматрање и анализу узимане су сложене творенице (сложенице и сраслице) настале слагањем или комбинованом творбом. Није нам био циљ да утврдимо крајњу мотивацију у настајању конкретне творенице па смо стога у грађу уврстили (и третирали као сложенице) и оне настале комбинованом творбом, односно конструкције настале суфиксацијом (ређе префиксацијом) којој је претходио процес композиције двају лексичко-семантички независних форманата (сложено-суфиксалне творенице $)^{4}$.

У корпусу ће бити приказане уазбучене сложене творенице у свом основном морфолошком облику, номинативу једнине за именске речи (номинативу једнине мушког рода за придеве, придевске заменице и редне бројеве) и инфинитиву за глаголе. Питање номинатива једнине придевских речи у мушком роду Вујић решава прилично недоследно. Своју улогу у томе имају различити фактори: графолошки, недостатак стабилног решења за фонему $j$; морфосинтаксички, несигурност и недоследност при обележавању одређеног и неодређеног вида придева; и на крају социолингвистички, употреба карактеристичног падежног завршетка, -ий или -їй (-їu) као индикатора припадности вишем регистру, или употреба, на пример, завршетка -ни, типичног за народни језик, такође прилично честа у нашем корпусу.

\footnotetext{
${ }^{3}$ Као што ћемо видети касније у раду, и са аспекта фреквентности првог форманта, и са аспекта конкурентности суфикса код сложеница са истим основама, резултати нашег истраживања у многоме ће се преклапати са наведеним у овом одељку.

${ }^{4}$ Теоријски оквир преузет је из монографије Творба речи у савременом српском језику. Први део. Слагање и префиксација Ивана Клајна из 2002. године у којој аутор даје преглед дефинисања сложених конструкција у нашим граматикама, од радова Т. Маретића с краја XIX века до анализе дела о творби речи и слагању у граматици Станојчић-Поповић с краја XX века.
} 
У корпусу ћемо стога придевске речи приказати у облику номинатива једнине мушког рода, у форми одређеног вида карактеристичној за тадашњи (славеносрпски) период, а, већим делом, и за сам Вујићев језички израз. Почев од радова Александра Младеновића такве форме у србистици се транскрибују са дугим $-u(-\vec{\imath})$ као адекватним падежним завршетком (пример: благопочтенородний (благопочтенородниј у издању које смо користили за ексцерпцију грађе) транскрибује се у благопочтенородни), па ћемо га и ми тако приказивати. Поједини примери из грађе сведоче о помињаној Вујићевој недоследности: карактеристичан славизирани облик (благополучи), али и форма ближа српском народном језику (благополучни). У таквим ситуацијама бележели смо оба примера ${ }^{5}$.

У тескту драме забележено је укупно 186 примера сложених твореница. Када се занемаре понављања и примери преведу на претпостављени лексикализовани облик, тај број је 117 , што представља $62 \%$ од укупног корпуса. Најфреквентније су сложенице са првим формантом благо-: забележен је 51 такав пример, што чини $27,5 \%$ укупног корпуса, дакле нешто више од $1 / 4$ свих забележених примера. Интересантно је истаћи да кад се занемаре понављања и узму у обзир само основни облици за дату врсту речи, тај број је 17, односно $33 \%$ укупног броја сложеница са првим формантом благо-. То нам говори да постоји велики број понављања, односно да су примери разуђени и равномерно заступљени у целокупном тексту драме.

\section{3. СЛОЖЕНЕ ТВОРЕНИЦЕ С ФОРМАНТОМ БЛАГО- И ЊИХОВИ АНАЛОГОНИ У САВРЕМЕНОМ СРПСКОМ ЈЕЗИКУ}

Анализирајући славенизме у песничком језику Петра Петровића Његоша, Светозар Стијовић у одељку Творбене и семантичке одлике славенизама у Његомевим песничким делима, конкретно творбени тип правих сложеница (праве, у којима је први део појмовна реч пуног лексичког значења), налази да су конструкције с формантом благо- најпродуктивније и наводи његове формантске парове: -говјеније, -дареније, -дарити, -дарност, -дат, -датан, -денствије, -дјеј, -душни, -родни, -родност, -родство, -словен, -словјати, -утробије, -уханије, -чиње (Стијовић1992: 101-105).

И у нашем корпусу сложенице с формантом благо- су најбројније, а велики део их се подудара са овим ексцерпираним из Његошевих дела, уз очекивана фонетска (дијалекатска) одступања. Сходно томе, анализу сложених твореница из Крешталице Јоакима Вујића с циљем утврђивања њихових аналогона у савременом језичком изразу, ограничићемо у нашем раду на ана-

${ }^{5}$ Корпус је у форми прилога дат на крају рада. 
лизу сложеница са формантом благо-. Оне би по проценту заступљености у самом корпусу требало да буду репрезентативан узорак за утврђивање степена адаптације тих конструкција у савремени српски језик.

У Славеносрпском језику Александар Младеновић анализирајући славеносрпске особине у језику Јована Стерије Поповића, тачније у језику његовог Романа без романа, то чини углавном кроз рускословенске и српскословенске елементе на фонетском плану. За нас је интересантно да међу ексцерпираним примерима који те елементе потврђују (различити типови завршетака именица) постоји и известан број сложеница са формантом благо-, те да се по броју њихових понављања, које аутор у раду даје, може закључити да је овакав тип сложеница и код Стерије био прилично продуктиван (Младеновић 1989: 115-134).

Разматрајући преведенице са грчког језика у Вуковом Рјечнику Светлана Слапшак такође истиче велику продуктивност сложених преведеница и псеудопреведенииа са фомантом благо- и то објашњава сфером употребе оваквих конструкција, јер сем ирквеног, означавају и световно комуницирање (Слапшак 1987: 45).

Говорећи о лингвистичком проблему кованица које представљају (лексички или синтагматски) јасно издвојен део фонда једног језика који је у великој мери ослоњен на богатство другог, туђег језика, где их дели на седам типова, Роберт Цет значајну пажњу посвећује и сложеним твореницама са формантом благо- (Цет 1970: 6-28).

Сложене творенице из приказаног корпуса представићемо кроз анализу њихових аналогона у савременом српском језику, а ослањајући се на најшири целовити речник савременог српског (српскохрватског) језика, Речник српскохрватскога књижевног језика Матице српске 1967-1976 (у даљем тексту PMC) ${ }^{6}$. Примери у корпусу су уазбучени и приказани у основном облику за дату врсту речи, и то онаквом који би коректно осликавао претпостављени граматички, морфонолошки, творбени и синтаксички систем Вујићева језика. Тај поступак није увек једноставан будући да Вујић себе декларише као славеносрпског писца ${ }^{7}$, а да су представници тога регистра, може се рећи, доследно недоследни у употреби славизираних елемената (рускословенских и српскословенских) с једне стране и елемената народног говора с друге стране.

${ }^{6}$ Уколико би се за одређени пример испоставило да његов евентуални аналогон не постоји у РМС, а да по језичком осећању савременог говорника (да се претпоставља да) треба да постоји или да постоји са другачијим значењем, биће консултовани Речник српскохрватског књижевног и народног језика Српске академије наука и уметности (РСАНУ), у мери у којој је то могуће, и Вуков Српски рјечник из 1852. године (ВУК 1852) .

${ }^{7}$ У појединим драмама на првој (насловној) страни налази се потпис са таквом пишчевом идентификацијом. У драми Карађорђе (Сербскиј вожд Георгиј Петрович) стоји: сочињено и написоно Јоакимом Вујићем славено-сербским литератором (Вујић 1987: 67). 


\section{Благоговено}

Не постоји потврда за овај облик у савременом српском језику, у РМС. У Речнику српскохрватског књижевног и народног језика Српске академије наука и уметности (РСАНУ) забележено је 5 одредница које улазе у лексичкограматички спектар ексцерпираног прилога, свих пет именичких, са различитим квалификаторима.

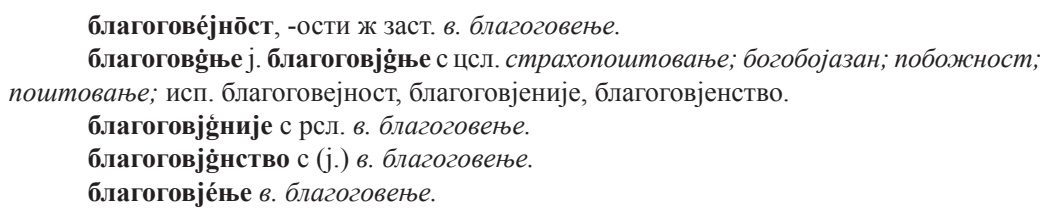

Квалификатори упућују на порекло лексеме, али и на чињеницу да се оне не осећају као део корпуса савременог српског језика. Лексички хипероним (лексичко језгро за ову групу примера), упућеница ${ }^{8}$ благоговење, на који се упућује у четири преостала примера, судећи по квалификатору води порекло из црквенословенског језика. Њему творбено синониман облик благовјеније по фонолошком решењу суфикса за грађење глаголске именице и имплицитно јекавском заменом ъ (јата) сврстава се у рускословенско језичко наслеђе. Преостала два примера представљају апстрактне именице различитог творбеног порекла и унеколико различитог значења, које се у речнику, ипак, не дефинише, већ се уз приложен цитат упућује на дефиницију надређене одреднице (сугерише да се погледа упућеница). Прва, благоговејност, женског је рода и квалификована је као застарела, док је друга, благоговјенство, средњег рода и квалификатором ( $j$ ) окарактерисана као репрезент јужног изговора ${ }^{9}$.

У драмском тексту потврђен је пример у прилошкој форми, и то у оквиру дидаскалије: Рибар (благоговено погледи у небо): Тамо оно више вреди неголи иелиј овај свет (Д1, И13). Из тога се да закључити да овај облик, са аспекта народнога језика и за то време евидентно маркиран, представља управо Вујићев језички израз јер не припада језику ниједног од протагониста драмске радње, чијим би се потенцијалним стилским пуњењем кроз коришћење славенизираних облика конкретни драмски лик додатно окарактерисао. Треба истаћи и чињеницу да РСАНУ бележи само именичке облике, док је ексцерпирани пример у форми прилога. Евентуални закључак који би се у вези са тим могао извести јесте да се, осим што се не осећају као део савременог језичког изра-

${ }^{8}$ Термин упућеница, који доследно користи Даринка Гортан Премк у својим радовима, и ми ћемо користити даље у раду.

9 У складу са тадашњом лексикографском праксом (прва свеска Речника је из 1959. године) лексемама су се могли додељивати квалификатори $u$. за источни изговор и $j$. за јужни изговор, што је требало да одговара екавској и јекавској конкуренцији на простору некадашњег српскохрватског језика. 
за, цитиране лексеме сматрају репрезентом црквеног, религијског дискурса, те да се њима дефинише став човека према духовом, према богу, и стога би очекивано било да се употребљавају у именичкој форми. С друге стране, корпус из кога је грађа за РСАНУ ексцерпирана ${ }^{10}$ могао је навести ауторе на овакав потез.

\section{Благодареније, благодарити, благодарност}

Први израз забележен је четири пута у тексту драме (3 пута у облику номинатива и једном у облику инструментала једнине) и одликује га суфиксална форма карактеристична за рускословенски дискурс. РМС овде даје два лексемска решења, творбено прилагођена српском језичком стандарду, различитог акцента и различитог значења,

благода́ре̄ње с гл. им. од благодарити.
благодаре́ње с обред захвалности

По контексту С великим благодаренијем примам ово ваше благодејаније (Д1, И9) или Госпоже, моје благодареније јест немо - једна суза радости. (Д2, И11) јасно је да је овде у питању прво наведено значење, за које можемо рећи да је неутралније и (у овом пару) стилски немаркирано.

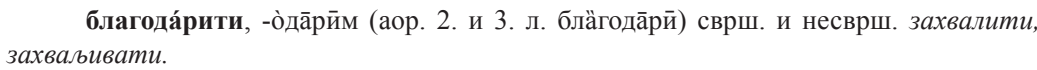

благода́рити, -о̀да̄рӣм (аор. 2. и 3. л. блӓгода̄рӣ) сврш. и несврш. захвалити, захваљивати.

Овај глагол се у тексту бележи доста често, а веома је интересантно истаћи да се доследно употребљава у облику 1. лица једнине презента, што се објашњава специфичном перформативном исказном формом (структурносемантичком формом захваљивања) која имплицира предикацију исказану 1. лицем једнине (евентуално множине) апсолутног презента.

благода́рно̄ст, -ости ж захвалност

За претходна три примера окупљена око семантичког језгра благодарваља напоменути да се у тексту драме бележе само двострука именичка и једна глаголска форма, док се у РМС (у форми аналогона, када је то фонолошки било потребно) уз именичке и глаголске бележе и придевски и прилошки облици. Ни за један од њих не дају се никакви квалификатори који би упућивали на застарелост или прецизирали на специфично порекло одређених облика. С аспекта савременог језичког осећања чини се да би се ипак дало дискутовати о застарелости ове групе лексема и потреби да се она у будућим речницима одређеним квалификаторима ипак детерминише као обележена лексика.

${ }^{10}$ Примери за ове лексеме су ексцерпирани из Гласника СПЦ, Правила православне иркве Николе Милаша, Нове искре из 1901. године, Његошеве Луче микрокозме, Позорника Войводства Србіе из 1849. године и сличних извора. 


\author{
Благодејаније \\ благод(ј)еја́ње с заст. помоћ сиромашним а добрим ученицима, стипендија, помоћ \\ уопите.
}

Даје се, дакле, суфиксално решење фонолошки прилагођено српском језичком стандарду, уз квалификацију застарелости. У корпусу је пример забележен доста пута, С великим благодаренијем примам ово ваме благодејаније (Д1, И9); Је ли то, дакле, моја благодарност за толика моја благодејанија? (Д2, И3), и првенствено се везује за последње наведено, уопштено значење, помоћ уопште ${ }^{11}$. Сходно томе евентуални аналогон у савременом језику била би управо лексема са доста општијим значењем, помоћ.

\title{
Благоизволети
}

благоизво̀лети, -изво̀лйм, ијек. благоизво̀љети (при исказивању нарочитог поштовања и ир.) изволети.

У тексту драме овај израз јавља се често, нарочито у оквиру пишчеве посвете, односно дела у коме исказује захвалност П. Стојановићу, финансијеру штампања драме. Припада, дакле, узвишеном стилу, дискурсу у којем су рускословенске црте изузетно фреквентне на свим нивоима, од фонетског и морфолошког до синтаксичког и фразеолошког.

Као што ћемо видети и из цитата ниже, дати глагол се употребљава у два облика: 2. лице множине императива и 2. лице множине перфекта (у оба случаја множински облици су доследно последица форме учтивости)....mpoшак тисненија благоизволели јесте штедрољубно на олтар просвештенија серпскаго человекољубно жертвовати, за которују причину благоизволите од мене всеусердно примити сеј мој малиј дарак... (ПП). Да бисмо боље разумели разлику у употреби овог глагола у Рајићеву језику у односу на данашњи, цитираћемо и значење глагола изволети из РМС:

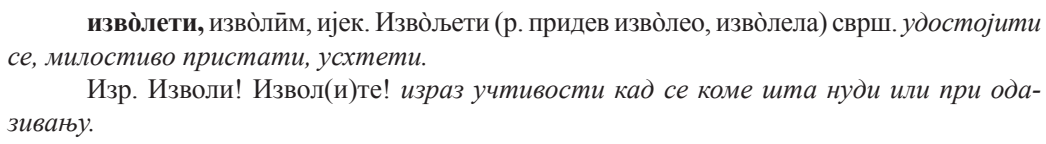

изво̀лети, изво̀лйм, ијек. Изво̀љети (р. придев изво̀лео, изво̀лела) сврш. удостојити се, милостиво пристати, усхтети.

Изр. Изволи! Извол(и)те! израз учтивости кад се коме шта нуди или при одазиваюу.

У данашњем језику глагол благоизволети се готово и не употребљава, евентуално, како то и дефиниција лексеме упућује, у изразито ироничним ситуацијама, опет везаним за језик литературе. И сам глагол изволети данас је сведен на употребу у форми израза учтивости или при одазивању. Ситуација је другачија када се анализира употреба његовог несвршеног пара изволевати

${ }^{11}$ РСАНУ бележи оба облика, и благодејаније с квалификатором цсл. и благодејање с квалификаторм заст. 
који чува своје место у данашњем разговорном језику. Дакле, перфекатски облик глагола изволети данас је у немаркираном дискурсу незамислив. У Рајићеву језику он је присутан у оба облика, с тим што треба нагласити да се везује само за значење дефинисано првим делом значења глагола изволети у PMC, уз наглашену учтивост коју доноси формант благо- ${ }^{12}$.

\section{Благополучије, благополучи, благополучан, благополучно}

Седамдесет миљи далеко долазим ја, ... ,овамо, зашто сам чуо да мом Михаилу благополучије часно указује се (Д2, И5), Пређе један бајскиј терговаи, благополучниј и доброимућиј, ... (Д1, И9), ...она су муктажије код нас по благополучним времену (Д1, И10), Јербо находи се пример да се један момак, после толико година благополучно и добрим задобивеним својим благом, опет $\kappa$ дому својему возвратио (Д1, И13)

Ниједан од примера који припадају семантичком језгру окупљеном око творбене основе благополуч- није забележен у РМС. У РСАНУ бележе се примери за све три морфолошке категорије потврђене примерима из корпуса, уз још једну, надређену именичку лексему, те једну глаголску лексему.

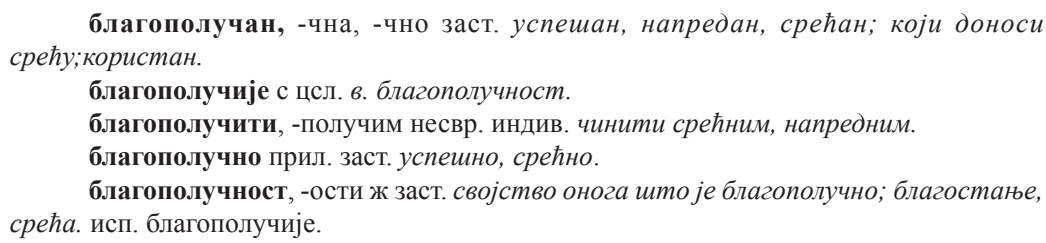

Уз три од пет лексема стоји квалификатор застарелости, за једну, морфонолошки и дериватолошки најстарију, се упућује на црквенословенско порекло (иако би се пре могло рећи да је то рускословенски облик), док се уз глаголску форму даје квалификатор индив. којим се објашњава да је наведени облик забележен само у једном од извора из изузетно великог корпуса грађе за РСАНУ (у корпусу је и велики број извора за које се може рећи да су под снажним црквенословенским и рускословенским утицајем). Тај податак нам даје објашњење за небележење глаголског облика лексеме у драмском тексту аутора који себе неретко декларише као славеносрпског писца. Именички аналогон благостање могао би се сматрати директним лексичко-семантичким

12 Да и глагол изволети има исто значење (пунозначно, а не само у форми израза учтивости), доказује и реплика у којој се употребљава истовремено и истозначно са глаголом благоизволети: ...сад мора се супружество наградити, а к тому опет за то био је муж узрок, зато, дакле, благоизволите добро искусити, милостива госпоже... Господар Жеравић био је свагда сердит, напрасит, злобан и пакостан човек - а ви сад изволите себи тражити таковог који ће бити веселе и пријатне нарави (Д1, И1). 
континуантом анализираног семантичког језгра. У РМС се управо именичка реализација једино и наводи.

\section{Благопочтенородије, благопочтенородни}

Ови примери, једнаке мотивационе базе, структурно се издвајају од готово свих ексцерпираних примера; они представљају два од три забележена примера из корпуса који се састоје из три форманта. У савременом говору рекло би се да су такви примери ретка појава; потврда за то може бити и непостојање аналогона за наведене примере у РМС, те чињеница да РСАНУ бележи придевску реализацију, али са квалификатором заст. Могло би се претпоставити да би се такви творбени модели могли пронаћи у дискурсима са изразито формализованим конструкцијама, чијим би се представницима могли сматрати језици цркве и дипломатије, и то они њихови делови који се односе на форме обраћања, указивања пажње и захваљивања између званичника тих институција ${ }^{13}$.

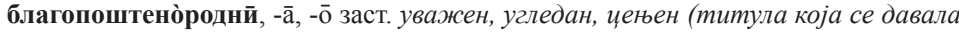
угледним грађанима).

Аналогон забележен у РСАНУ је фонолошки, акценатски и творбено прилагођен српском стандардном језику. Ако упоредимо примере из корпуса са примерима датим у речнику уз лексему, видећемо да су контекстуално веома слични, те да су и везани за исти период развоја нашег књижевног језика ${ }^{14}$. Постојање и именске реализације у тексту драме (почтенородије) доказ је да је Вујићев језик, нарочито онај издвојен од језика драмских реплика, аутентичан представник славеносрпског језика.

\section{Благопријатност}

У РМС није забележена лексема творбено и значењски сродна овој, док се у РСАНУ бележе придевска и именичка варијанта, обе с квалификатором који упућује на застарелост.

${ }^{13} \mathrm{Y}$ РМС се бележи лексема високопреосвештѐнство с цркв. титула архиепископа $u$ митрополита у православној цркви, за коју се може рећи да је троформантска сложеница, с тим што други од три форманта у овом примеру нема независно лексичко-семантичко значење. Употребљава се (како квалификатор и упућује) приликом обраћања поглаварима православне цркве, чешће у краћој форми преосвештенство, која, занимљиво, у истом речнику има другачији квалификатор, цсл.

${ }^{14}$ Благопочтенородном господару Петру Стојановичу, гражданину и купиу староарадскому, ... (пишчева посвета на насловним странама драме, у којој се захваљује пријатељу који је омогућио њено штампање), и имена г. г. пренумераната ... Осијек ... Г. Г. Аргировић, трговаи, грађанин и градски заступник (први део из дефиниције у РСАНУ где се наводи да је то цитат из Вукових народних пословица). 
благопрйја̄тан, -тна, -тно (рус. благоприятный) заст. врло пријатан, угодан. благоприја́тно̄ст, -ости ж заст. велика пријатност, задовољство.

У драмском контексту - била једна песма која употребљаваше се ради благопријатности моје садашње свободе и мене такође советоваше не опет тако скоро мени на главу мрежу набацитти допуштати (Д1, И1). У овом, мало ширем, цитату може се констатовати славизираност језичког израза на различитим граматичким плановима: типичне фонетске алтернације (свободе, советоваше), употреба имперфекта (употребљаваше, саветоваше) као морфолошки индикатор, карактеристичан ред речи као синтаксички архирепрезент славеносрпског, и на крају, наш цитирани пример, аутентични модел творбе речи тог дискурса (благопријатности).

Пројектовани аналогони у савременом језику били би баш онакви какви су дати у РСАНУ, дакле синтагматски, односно аналитички, велика (или сл.) пријатност или лексички супституент, са истим или веома сличним значењем, задовољство.

\section{Благородниј, благородство, високоблагородије}

У РМС забележено је чак седам лексема које покривају лексичко-семантичко језгро ових ексцерпираних примера

\footnotetext{
благо̀родан, -дна, -дно 1. добар, племенит, душеван, захвалан. 2. (само одр.) који је племенитог рода, (у титулама, понекад ир.). 3. који је добре врсте.

благо̀роднйк м благородан човек, племић.

благоेродничкй, -a, -о који се односи на благороднике.

благо̀родно прил на благородан начин, пријатно, захвално.

благоро̀дно̄ст -ости ж особина онога који је благородан, доброта.

благоро̀дство с 1. в. благородност. 2. рус. заст. племићка или чиновничка титула.

благо̀рође с заст. 1. в. благородност 2. в. благородство (2).
}

Именица благородник (и придев благороднички) се издваја будући да представља другачији творбени модел, модел моционе суфиксације, са суфиксном морфемом -(н) $\bar{u} \kappa$, а и могла би се сврстати у творбени подразред nomina attributiva ${ }^{15}$.

За придев благородниј логичан избор аналогона био би придев благородан наведен у РМС са једним од три наведена значења и за њега се може констатовати да је лексички хипероним, упућеница, за цитирану групу примера. У драмском тексту Дакле, ваш господин није рождениј благородниј? (Д1, И11) имамо поименичавање придева (у формама обраћања, најчешће ауторитетима,

15 Говорећи о продуктивности овог творбеног типа, Божо Ћорић каже да увек треба да имамо у виду све тешкоће у вези са издвајањем овог творбеног типа у подразреде. Неки од разматраних феминина могли су ићи у потіna agentis и обратно (Ћорић 1982: 51). 
конкретним и апстрактним), те би се он такав везао за друго наведено значење у РМС, и одређену придевску форму. Свакако да и ова појава представља једну од иманентних стилских карактеристика у области творбе речи у славеносрпском дискурсу. Аналогон би онда пре био именички, благородник или једноставније и стилски немаркирано племић.

Именица благородство, једном забележена у тексту драме, Ја нисам био на юеговом рожденију и арма благородства у материној утроби весма нечитајемо притискава се (Д1, И11), аналошки је прецизно потврђена у дефиницији те лексеме у РМС.

Троформантска именица високоблагородије само је индиректно потврђена у РМС, приликом дефиниције форманта високо-

високо- као први део сложеница значи в. ист. у титулама: високоблагородни, високопреосвећени.

У РСАНУ ситуација је слична, наводи се приликом дефинисања форманта високо-, али се дају и четири независне дефиниције, једна придевска и три именичке, при чему је упућеница управо високоблагородије.

високоблагоро̀дије с. (рус. высокоблагородие) заст. некадашња титула виших чиновника и официра.

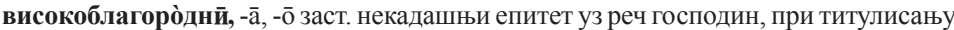
виших чиновника и официра.

високоблагороेдно̄ст, -ости ж заст. в. високоблагородије.

високоблагороेдство с заст. в. високоблагородије.

Код све четири лексеме квалификатором се упућује на застарелост, а у дефиницији (некадашња титула, некадашњи епитет) се то и експлицитино наглашава. Сходно томе можемо закључити да у савременом српском језику не постоји аналогон ове именице. Евентуална њена данашња употреба дискурсно би била ограничена слично претходно анализираној троформантској лексеми благопоштенородни.

\section{Благослов, благословити}

Од свих ексцерпираних ове две лексеме су најзаступљеније у савременом језику. Уз то, за њих се може тврдити да се у најмањој мери осећају као обележена лексика, како са аспекта застарелости, тако и са аспекта припадности неком од историјских регистара српског књижевног језика. То потврђује и број одредница у РМС окупљених око семантичког и творбеног језгра благослов- - осамнаест. Морфолошки спектар је веома разуђен па тако имамо: шест именских реализација, где уз упућеницу имамо и глаголску и апстрактну именицу, те одреднице са квалификаторима цркв. и покр; по три придевске и прилошке одреднице, где ваља напоменути бележење и јекавских облика као 
још један индикатор заступљености у савременом језичком изразу; и шест глаголских одредница уз присуство видских парова. Из свега тога може се закључити да су аналогони ексцерпираних лексема управо њихови директни континуанти.

Стога, навешћемо само дефиницију речничке упућенице из РМС.

благосло̀вити, -о̀сло̄вӣм (имп. благосло̀ви, аор. 2. и 3. л. блӓгословй) сврш. 1. дати благослов, изразити жељу за нечије добро и срећу. 2. цркв. извриити обред освећења, осветити. 3. а. рлг. обдарити (о богу). б. фиг. ир. изударати, измлатити. 4. одобрити.

\section{Благочестије}

Последњи пример сложених твореница с формантом благо- индиректно је потврђен је у РМС једном дефиницијом; у питању је дублетни облик придева:

благоча̀стив и благочѐстив, -a, -о арх. смеран, смирен, побожан.

Иако је квалификација архаичности овде заједничка за оба примера, јасно је да по пореклу припадају различитим типовима српског језичког стандарда.

Пример је ексцерпиран из предговора тексту драме, коториј јего високоблагородије Урош Стефан Новаковић, ... , недавно в предуготованије детонаставников благочестија нашего водрузио јест (П). Употреба именске реализације ове лексеме у тексту драме потврђује ранију тезу да предговор представља доста славизиранији пример Вујићева језика будући да се у њему писац обраћа различитим ауторитетима, грађанским и црквеним, те је такав дискурс био, у најмању руку, пожељан.

РСАНУ нам даје чак десет различитих лексемских реализација, од чега чак седам именских, са различитим степеном фонолошке, морфонолошке и творбене адапатације.

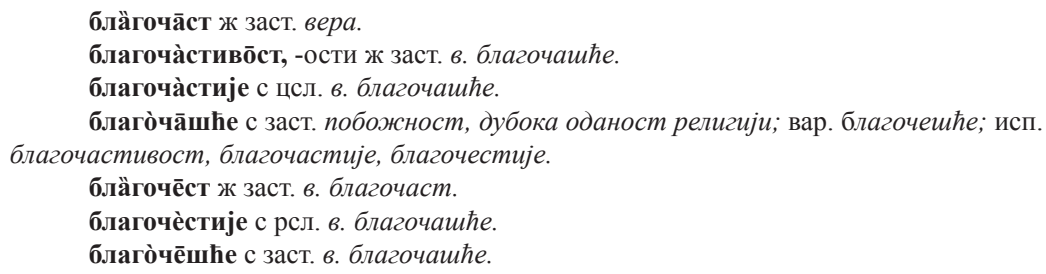

Судећи по упућеницама именске дефиниције можемо раздвојити на две групе. Прву чини пар апстрактних именица са значењем вера, а другу пет именица с упућеницом благочашће. Заједнички им је квалификатор застарелости, с тим да се поједине лексеме додатно издвајају пројекцијом у неки од 
ранијих регистара стандардног (књижевног) језика у Срба. Директни аналогон ексцерпираном примеру, дакле, не постоји, а аналитички аналогон била би дефиниција саме упућенице, побожност, дубока оданост религији, при чему би се дало расправљати о евентуалним померањима у дефинисању, а на основу нашег примера, али и примера ексцерпираних у осталим текстовима из периода језичке полиглосије.

\section{4. ЗАКЉУЧАК}

Анализирајући само један аспект Вујићева језика дошли смо до закључка да он заиста јесте аутентичан представник времена у којем ствара, уз, нужне и драгоцене, индивидуалне карактеристике које га суштински и чине славеносрпским литератором. Једна од иманентних карактеристика славеносрпског језика, као креираног вишег регистра српске литературе тога времена, јесте и употреба сложеница. У тексту Крешталице има их заиста доста, а немали број њих је присутан, ако не у савременом језичком изразу, оно бар у речницима савременог (и народног) српског језика.

Степен адаптације сложеница из драме у савремени језички израз могли бисмо дефинисати кроз присуство датих лексема у одређеним речницима са одређеним квалификаторима или без њих. Уколико је пример сложенице (сложене творенице) забележен у РМС, дакле у речнику савременог језика, и то без икаквих квалификатора, можемо рећи да је трансфер дате лексеме у савремени језичи израз потпун. Такве су лексеме благослов и благословити, као и поједине реализације лексема из лексичко-семантичких језгара благодар(благодарити) и благород- (благородан). Уколико, пак, пример дате сложене конструкције није забележен у РМС, већ само у РСАНУ, речнику књижевног и народног језика, те по правилу иде уз различите квалификаторе (заст, арх, цсл, рсл), закључићемо је да је степен адаптације те лексеме веома мали, а да је њен трансфер у савремени језик остварен преко адекватног (најчешће доста општијег) синонима (пр. благодејаније : помоћ).

Језик Јоакима Вујића је, како смо видели, само благо осветљен. Могли бисмо рећи да структуру и законитости Вујићева језика верније приказују студије о језичким карактеристикама његових савременика, него што то успевају неколики изоловани радови о језику његових драмских и других дела. Српској лингвистици неопходно је да се радовима Александра Албијанића у скоријој будућности придруже нови радови којима би се језик Јоакима Вујића барем с приближним успехом приказао као језик других представника српске књижевности и културе XVIII и XIX века. 


\section{5. ЛИТЕРАТУРА}

Албијанић 1976: Александар Албијанић, „Прилог познавању судбине српскословенских елемената у језику писаца из Војводине предвуковског периода" у: Зборник Матице српске за филологију и лингвистику, XXIX/2, Нови Сад: Матица српска, 37-53.

Албијанић 1981: Александар Албијанић, „Прилог познавању деклинирања позајмљеница у неким делима Јоакима Вујића" у: Научни састанак слависта у Вукове дане 7/1, Београд: Филолошки факултет, $113-122$.

Албијанић 1982: Александар Албијанић, „Од рационализма ка романтизму: Кратак осврт на позоришни језик Јоакима Вујића" у: Научни састанак слависта у Вукове дане 12, Београд: Филолошки факултет, 43-53.

Албијанић 1983: Александар Албијанић, „Кратак осврт на најмаркантније фонетске, морфолошке и синтаксичке особине језика Јоакима Вујића" у: Зборник Матице српске за филологију и лингвистику, XXVI/2, Нови Сад: Матица српска, 73-79.

Албијанић 1983: Александар Албијанић, „Однос између домаћих и рускословенских елемената у језику прокламација Јосифа II штампаних 1788. године" у: Зборник Матице српске за филологију и лингвистику, XXVI/2, Нови Сад: Матица српска, 65-72.

Албијанић 1985: Александар Албијанић, „Језик белетристике Јоакима Вујића” у: Научни састанак слависта у Вукове дане 14/3, Београд: Филолошки факултет, 69-78.

Албијанић 1986: Александар Албијанић, „Језик нештампаних драма Јоакима Вујића" у: Зборник Матице српске за филологију и лингвистику, XXIX/1, Нови Сад: Матица српска, 113-125.

Гутков 2005: Владимир Гутков, Славистика - србистика, Београд: Завод за уџбенике и наставна средства; Вукова задужбина; Нови Сад: Матица српска.

Јерковић 1976: Јован Јерковић, Језик Богобоја Атанаџковића, Нови Сад, Матица српска.

Кашић 1968: Јован Кашић, Језик Милована Видаковића, Нови Сад, Филозофски факултет.

Клајн 2002: Иван Клајн, Творба речи у савременом српском језику. Део 1. Слагање и префиксаиија, Београд: Завод за уџбенике и наставна средства. 
Клајн 2003: Иван Клајн, Творба речи у савременом српском језику. Део 2. Суфиксаиија и конверзија, Београд: Завод за уџбенике и наставна средства.

Куна 1970: Herta Kuna, Jezičke karakteristike književnih djela Dositeja Obradovića, Djela, XXXVI, knj. 21, Sarajevo: Akademija nauka i umjetnosti Bosne i Hercegovine, Odjeljenje istorijsko-filoloških nauka.

Милановић 2013: Александар Милановић, Језик весма полезан, Београд: Друштво за српски језик и књижевност Србије.

Милановић 2014: Александар Милановић, Језик Јована Суботића, Београд: Филолошки факултет.

Младеновић 1989: Александар Младеновић, Славеносрпски језик, Нови Сад: Књижевна заједница Новог Сада.

Никитовић 2014: Зорица Никитовић, Сложенице у оригиналним српскословенским дјелима сакралног карактера, Бања Лука: Филолошки факултет.

Речник МС 1967-1976: Речник српскохрватскога књижевног језика, т. I-VI, Нови Сад: Матица српска.

Речник САНУ 1959-2010: Речник српскохрватског књижевног и народног језика, т. I-XVIII, Београд: Српска академија наука и уметности.

Слапшак 1987: Светлана Слапшак, Вуков Рјечник и преведенице са грчког, Нови Сад: Књижевна заједница Новог Сада.

Станојчић/Поповић ${ }^{82000: ~ Ж и в о ј и н ~ С т а н о ј ч и ћ, ~ Љ у б о м и р ~ П о п о в и ћ, ~ Г р а м а т и-~}$ ка српскога језика, Уибеник за I, II, III и IV разред средње школе, Београд: Завод за уџбенике и наставна средства.

Стијовић 1992: Светозар Стијовић, Славенизми у Његомевим песничким делима, Нови Сад, Издавачка књижарница Зорана Стојановића.

Суботић 1989: Љиљана Суботић, Језик Јована Хаџића, Нови Сад: Матица српска.

Толстој 2004: Никта Толстој, Студије и чланщи из историје српског књижевног језика, Београд: Завод за уџбенике и наставна средства; Вукова задужбина; Нови Сад: Матица српска.

Ћорић 1982: Божо Ћорић, Моциони суфикси у српскохрватском језику, Београд, Филолошки факултет.

hорић 2008: Божо Ћорић, Творба именица у српском језику, Београд, Друштво за српски језик и књижевност Србије. 
Херити 1983: Питер Херити, Књижевни језик Емануила Јанковића, Нови Сад, Матица српска.

Цет 1970: Robert Zett, Beiträge zur Geschichte der Nominalkomposita im Serbokroatischen. Die alterserbische Periode, Köln-Wien: Böhlau Verlag.

\section{6. СКРАЋЕНИЦЕ}

Д- дејствије (Д1, Д2, Д3)

И - исход (И1, И2, ... И13)

П - предисловије

ПП - пишчева посвета

РМC - Речник српскохрватскога књижевног језика, Матица српска.

РСАНУ - Речник српскохрватског књижевног и народног језика, Српска академија наука и уметности.

\section{7. КОРПУС}

$\begin{array}{lll}\text { Благоговено } & \text { Два-три } & \text { Первозорник } \\ \text { Благодареније } & \text { Двогуби } & \text { Полудневни } \\ \text { Благодарити } & \text { Двоумити } & \text { Послеполдне } \\ \text { Благодарност } & \text { Десјатогодишњи } & \text { Почтенородије } \\ \text { Благодејаније } & \text { Детонаставник } & \text { Праводушно } \\ \text { Благоизволети } & \text { Добродетелно } & \text { Православни } \\ \text { Благополучи } & \text { Добродетел } & \text { Предисловије } \\ \text { Благополучије } & \text { Добродетељ } & \text { Простодушно } \\ \text { Благополучни } & \text { Доброимућиј } & \text { Противстајати } \\ \text { Благопочтенородије } & \text { Доброхотство } & \text { Равнодушан } \\ \text { Благопочтенородни } & \text { Домостројеније } & \text { Равнодушно } \\ \text { Благопријатност } & \text { Достоверно } & \text { Руже-цервени } \\ \text { Благородни } & \text { Драговољно } & \text { Самоиздајеми } \\ \text { Благородство } & \text { Жестокосердије } & \text { Сант-Доминго } \\ \text { Благослов } & \text { Западноиндијски } & \text { Свезнајушти } \\ \text { Благословити } & \text { Западопловитељ } & \text { Свето-Андреја } \\ \text { Благочестије } & \text { Злодеј } & \text { Славено-серпскиј } \\ \text { Богољубић } & \text { Злонравни } & \text { Совокупно } \\ \text { Бракосочитаније } & \text { Злословије } & \text { Староарадски } \\ \text { Братољубије } & \text { Једанпут } & \text { Стихотворец } \\ \text { Вековечни } & \text { Кадгод } & \text { Таконоречени } \\ \text { Великодушије } & \text { Кад-који } & \text { Треклети } \\ \text { Великодушно } & \text { Каменосердечни } & \text { Трепетоужасно } \\ & & \end{array}$




\begin{tabular}{|c|c|c|}
\hline Великоможни & Каменотверди & Тридневни \\
\hline Вероисповеденије & Којекуд & Тролетни \\
\hline Визиткарта & Коребљекрушеније & Трудољубиви \\
\hline Високоблагородије & Користољубље & Трудољубије \\
\hline Високопочитаније & Краснопјеније & Трудољубни \\
\hline Високопочитовати & Красноречиви & Тштеславни \\
\hline Всеблаги & Красноречије & Тшчеславије \\
\hline Всемогушти & Љубопитни & Церномањаст \\
\hline Всесилни & Љубопитно & Црвоточни \\
\hline Всеусердно & Љубопитство & Человекољубно \\
\hline Гдигод & Маловерни & Человечество \\
\hline Глувопрда & Мало-помало & Човекољубије \\
\hline Гологлави & Милосердије & Штедрољубно \\
\hline Горуименовани & Народољубац & Штогод \\
\hline Громогласно & Новозаведени & \\
\hline Двапут & Нравоученије & \\
\hline
\end{tabular}

\section{Summary}

In this paper we analyzed complex derivatives we found in the Joakim Vujic's play "Krestalica". Extensive and comprehensive formal morphological analysis of the compounds with the formant blago-, including citation of drama's context, helped us to find analogoues of them in modern serbian language and define model adaptation (transfer model) of such compounds into todays linguistic usage. 